\title{
Covid-19: International staff are considered vital to NHS's efforts, survey finds
}

\author{
Abi Rimmer
}

The BMJ

The public would support a new deal for international NHS and social care staff, a survey commissioned by the Royal College of Physicians (RCP) has found.

The college is calling on the government to recognise the vital role that international staff are playing in the frontline response to covid-19. It said that this call was supported by a poll of 1679 UK adults, in which $67 \%$ thought it unlikely that the NHS would have been able to tackle the coronavirus without international staff.

As part of a new deal for international staff the RCP is asking for all NHS and social care staff, and their spouses and dependants, to be exempt from the international health surcharge. The surcharge means that staff from outside the European Union can be forced to pay $£ 400(€ 451 ; \$ 490)$ a year to use the health service despite paying tax and national insurance. ${ }^{1}$ The BMA has also called for all healthcare workers to be exempt from this charge.

The RCP is also calling for all NHS and social care staff who have worked during the pandemic to be given indefinite leave to remain, as well as their spouses and dependants. A similar call has been made by the BMA and the British Association of Physicians of Indian Origin (BAPIO).

\section{NHS visa}

In a letter sent to the UK home secretary earlier this month Ramesh Mehta, BAPIO president, said, "The least the government could do now is to take away the additional obstacles for [international medical professionals] to feel as part of this country ... helping them to continue to provide fantastic contributions to the NHS and the UK."

The RCP is also calling for the proposed NHS visa to be extended to social care staff. The NHS visa was first proposed by the Conservative Party in November 2019. Under the system, workers applying for NHS posts will pay half the normal visa fee ( $£ 464$ rather than $£ 928$ ), and their applications will be fast tracked and treated more favourably. ${ }^{2}$

In support of its call the RCP commissioned a YouGov poll, which received 1679 responses from adults in the UK. Of those who responded, 59\% thought that international staff who have worked in the NHS during the coronavirus pandemic should have the right to stay in the UK permanently.

A further 59\% thought that international NHS and social care staff should not have to pay the NHS surcharge, and $69 \%$ called for the government to publicly acknowledge their invaluable contribution.

Andrew Goddard, RCP president, said there was no doubt that the NHS would be unable to cope without the contribution of international staff. "Their work throughout the covid-19 pandemic has been crucial to saving lives, and our polling results today clearly show that the public share our eagerness to reward them for their commitment and dedication," he said. "The government has an opportunity to reset the narrative and make the NHS a truly welcoming place to work for everyone. I hope they seize it."

A government spokesperson commented, "We have already announced the extension of visas for approximately 3000 frontline health and care professionals, both in the NHS and in the independent sector. These extensions will be automatic, free and include exemption from the immigration health surcharge. We will continue to work to see how best we can support health and care workers."

1 Rimmer A. Help end NHS fees for overseas doctors, campaigners tell medical institutions. BMJ 2019:365:|2348, 10.1136/bmj. I2348 31138541

lacobucci G. UK will still attract overseas doctors despite ending free movement, government insists. BMJ 2020;368:m942. 10.1136/bmj.m942 32144174

Published by the BMJ Publishing Group Limited. For permission to use (where not already granted under a licence) please go to http://group.bmj.com/group/rights-licensing/ permissions 